\title{
STRES KERJA SHIFT MALAM DAN KINERJA PERAWAT PELAKSANA DI RUANG RAWAT INAP
}

\author{
Ahsan, Humaera Hafid \\ Program Studi IImu Keperawatan \\ Fakultas Kedokteran Universitas Brawijaya \\ E-mail: ahsanfkub@yahoo.com
}

\begin{abstract}
ABSTRAK
Tujuan penelitian: Tujuan penelitian ini ialah mengetahui adanya hubungan antara stres kerja shift malam dan kinerja perawat pelaksana di ruang rawat inap Rumah Sakit Wava Husada Kepanjen, Kabupaten Malang. Metode: Desain penelitian ini ialah penelitian korelasional dengan sampel 30 perawat yang bekerja di ruang rawat inap RS Wava Husada tahun 2014, menggunakan teknik purpose sampling. Hasil data dianalisis dengan uji statistik, yaitu Fisher probability exact test. Hasil: Sebagian besar perawat shift malam berada pada klasifikasi stres ringan, yaitu 16 perawat atau sebanyak 53,3 persen. Sebagian besar berada pada klasifikasi baik (23 perawat atau sebanyak 76,7 persen). Diskusi: Petugas kesehatan disarankan untuk mengetahui efek stres kerja terhadap kinerja perawat sebagai upaya untuk meningkatkan kinerja perawat. Simpulan: Ada hubungan antara stres kerja shift malam dan kinerja perawat pelaksana.
\end{abstract}

Kata Kunci : kinerja, shift malam, stres kerja.

\section{ABSTRACT}

Objective: This study is aimed at identifying the correlation between stress due to night-shift work and nurse performance in providing nursing care at inpatient wards of Wava Husada Hospital, Kepanjen, Malang Regency. Methods: This study employed correlational design with a sample size of 30 nurses working at inpatient wards of Wava Husada Hospital in 2014 and taken using purpose sampling. Data were analyzed with using Fisher probability exact test. Results: This study indicated that 16 nurses (53.3\%) working the night-shift were low level of stress. Most of nurses (23 nurses or 76.7\%) were in the category of good. Discuss: It is recommended that healthcare workers know the effects of work-related stress on nurse performance in order to increase nurse performance. Conclusion: It can be concluded that there is a correlation between stress due to night-shift work and nurse performance.

Keywords: performance, night-shift, work-related stress.

\section{LATAR BELAKANG}

Perubahan ilmu pengetahuan, teknologi, dan globalisasi dunia berdampak secara langsung terhadap sistem pendidikan dan pelayanan kepada masyarakat, termasuk pelayanan kesehatan. Tuntutan atas pelayanan kesehatan berkualitas yang diberikan semakin meningkat. Rumah sakit sebagai institusi yang mempunyai fungsi dan tugas memberikan pelayanan kesehatan kepada masyarakat secara paripurna juga merupakan organisasi yang sangat kompleks karena sumber daya manusia yang bekerja terdiri atas berbagai disiplin ilmu dan jenis keahlian. Rumah sakit merupakan salah satu bentuk organisasi yang kegiatannya memberikan pelayanan yang baik berupa promotif, preventif, kuratif, dan rehabilitatif. Untuk mencapainya, dibutuhkan kinerja karyawan, khususnya perawat yang baik yang sifatnya subjektif, dipengaruhi oleh umur, jenis kelamin, sikap mental, kepribadian, pendidikan (Retyaningtyas, 2005). 
Sumber daya manusia yang terlibat secara langsung dalam pemberian pelayanan kepada pasien rumah sakit sekitar 40 persennya ialah tenaga perawat (Hasibuan, 2009). Pelayanan keperawatan merupakan bagian integral dari sistem pelayanan kesehatan sehingga kepentingan pelayanan keperawatan mempunyai arti penting bagi klien selama 24 jam secara terus-menerus, khususnya dalam proses penyembuhan maupun rehabilitasi di rumah sakit Departemen Kesehatan Republik Indonesia (Depkes RI, 2008).

Dalam berkegiatan, pekerja rumah sakit terpapar bahaya potensial seperti radiasi, bahan kimia beracun, bahaya biologis, panas, bising, debu, dan stres. Untuk melindungi pekerja dari semua faktor bahaya yang ada, diterapkan kesehatan dan keselamatan kerja (K3) di rumah sakit. Penerapan K3 di rumah sakit bertujuan untuk menekan serendah mungkin risiko kecelakaan dan penyakit yang timbul akibat hubungan kerja serta meningkatkan produktivitas dan efisiensi.

Demi tercapainya pelayanan kesehatan yang maksimal, efisien, dan hasil kinerjanya dapat dirasakan sepenuhnya oleh masyarakat dalam 24 jam, diperlukan 3 shift kerja, yaitu shift pagi: pukul 06.00-14.00, shift siang: 14.00-22.00, dan shift malam: pukul 22.00-06.00 (Sedarmayanti, 2006).

Jenis stressor yang diungkapkan oleh perawat berkaitan dengan shift malam salah satunya ialah perawat yang bertugas pada malam hari lebih sedikit, lamanya dinas atau jam bekerja yang lebih panjang daripada shift yang lainnya, dan jumlah pekerjaan yang harus diselesaikan pada shift malam lebih banyak. Pada shift malam hanya ada dua perawat yang bekerja dan fokus terhadap pasien, tidak ada perawat pengganti dalam pengoperasian alat. Efek fisiologis yang ditimbulkan misalnya pandangan kabur, kepala terasa pusing, buang air besar (BAB) tidak lancar, perut terasa mual dan perih, badan terasa sangat letih, dan lain-lain. Efek psikososial yang ditimbulkan misalnya mudah marah atau tersinggung, bersikap kurang sabar, merasa jiwanya tertekan, dan lain-lain. Efek-efek tersebut tentunya dapat menurunkan prestasi kerja perawat, seperti penurunan konsentrasi dan penurunan kewaspadaan sehingga akan memengaruhi mutu pelayanan kesehatan di suatu rumah sakit (Stuart, 2007).

Konsep stres kerja dinyatakan sebagai agen penyebab berbagai masalah fisik, psikologis, bahkan output karyawan dalam organisasi. Banyak studi yang menghubungkan stres kerja dengan berbagai hal, misalnya stres kerja dengan kepuasan, kesehatan mental, ketegangan, ketidakhadiran, dan kinerja (Sedarmayanti, 2006). Stres kerja tidak hanya berpengaruh terhadap individu, tetapi juga terhadap biaya organisasi dan industri. Tingkat stres tinggi dapat menimbulkan kerentanan penyakit atau "distress" dan memberikan gejala fisik dan psikologis (Stuart, 2008). Manifestasi stres yang dialami seseorang dapat dilihat dari perubahan perilaku (behavior change).

Badan statistik Indonesia belum mengeluarkan data khusus tentang jumlah karyawan yang mengalami stres kerja. Dinas Kesehatan DKI Jakarta mengungkapkan 11,6 persen atau 17,4 juta jiwa mengalami gangguan mental emosional atau gangguan kesehatan jiwa berupa gangguan kecemasan dan depresi. Gangguan kejiwaan kecemasan dan depresi yang diakibatkan stres kerja atau yang berhubungan dengan tempat kerja sebesar 37 persen atau 6,4 juta jiwa. Angka tersebut diperoleh dari survei kesehatan daerah tentang gangguan jiwa mental dan emosional oleh Kementerian Kesehatan (Depkes RI, 2008).

Perawat merupakan pekerjaan yang mempunyai tingkat stres yang tinggi karena saat bekerja, perawat berhubungan langsung dengan berbagai macam pasien 
dengan diagnosis penyakit dan respons yang berbeda-beda (Desak, 2008). Tingginya stres yang dialami perawat dalam bekerja membuatnya jenuh dan bosan, akhirnya berpengaruh terhadap produktivitas kerja dan menyebabkan penurunan kinerja perawat (Hasibuan, 2009).

Berdasarkan pembahasan tersebut, salah satu masalah di ruang rawat inap yang bisa diungkapkan ialah standar praktik keperawatan sebagai pedoman kerja tenaga profesional keperawatan dalam melaksanakan asuhan keperawatan. Perawat di ruang rawat inap perlu mengetahui sumber-sumber atau faktorfaktor stres supaya mampu mengembangkan manajemen stres dalam upaya meningkatkan kinerja yang tepat sehingga terjalin hubungan baik dengan teman sejawat, pimpinan, dan tim kesehatan yang lain (Hasibuan, 2009).

Alasan penelitian ini dilakukan di Rumah Sakit Wava Husada Kepanjen ialah karena rumah sakit ini banyak menerima pasien sehingga aktivitas kerja perawat shift malam benar-benar dipertaruhkan kinerjanya. Pihak manajemen rumah sakit sedang berusaha meningkatkan kualitas layanan di seluruh sektor sehingga penelitian ini dapat dijadikan masukan yang positif.

Fenomena dan latar belakang tersebut membuat penulis tertarik melakukan penelitian tentang hubungan stres kerja shift malam dengan kinerja perawat pelaksana di ruang rawat inap RS Wava Husada Kepanjen, Kabupaten Malang.

\section{METODE}

Penelitian ini menggunakan desain penelitian analisis korelasional, yakni penelitian ini bertujuan mencari hubungan antara stres kerja perawat shift malam dan kinerja perawat di RS Wava Husada Kepanjen, Kabupaten Malang. Perawat yang menjadi sampel dalam penelitian ini ialah perawat yang bekerja di ruang rawat inap RS Wava Husada, yaitu sebanyak 30 orang yang memenuhi kriteria inklusi di ruang perawatan $\mathrm{C}$ dan $\mathrm{D}$. Penelitian ini menggunakan teknik pengambilan sampel purpose sampling, yaitu responden yang berjumlah 32 orang diberikan kode responden masing-masing, kemudian dilakukan pengundian sesuai keinginan yang diharapkan sampai mendapatkan sampel 30. Setelah mendapatkan surat persetujuan penelitian dari Tim Tugas Akhir Fakultas Kedokteran Universitas Brawijaya (TA FK UB), peneliti kemudian melakukan penelitian di RS Wava Husada Kepanjen, Kabupaten Malang selama 1 bulan. Kuesioner dibagikan sekaligus untuk responden dengan jumlah 30 orang.

Lokasi penelitian ini dilakukan di RS Wava Husada Kepanjen, Kabupaten Malang. Waktu penelitian dimulai sejak 15 Desember sampai 27 Desember 2014. Teknik pengumpulan data dalam penelitian ini ialah dengan menggunakan alat atau instrumen penelitian berupa angket atau kuesioner yang dirancang berdasarkan faktor-faktor yang berhubungan dengan stres kerja. Kuesioner ini dikonsultasikan kepada tim pembimbing dengan validitas dan reliabilitas 0,05 .

Teknik analisis data menggunakan analisis univariat untuk menjelaskan atau mendeskripsikan karakteristik variabel penelitian dan analisis bivariat untuk mencari hubungan tentang stres kerja perawat shift malam dengan kinerja perawat. Perhitungan data untuk keperluan analisis menggunakan uji statistik metode spearman rank. 
HASIL

Tabel 1. Distribusi responden berdasarkan karakteristik usia, jenis kelamin, pendidikan, stres kerja, dan kinerja

\begin{tabular}{|c|c|c|c|c|c|c|c|c|c|c|c|c|}
\hline \multirow{2}{*}{ No } & \multirow{2}{*}{ Usia } & \multicolumn{2}{|c|}{$\begin{array}{l}\text { Jenis } \\
\text { Kelamin }\end{array}$} & \multicolumn{3}{|c|}{ Pendidikan } & \multicolumn{3}{|c|}{ Stres Kerja } & \multicolumn{3}{|c|}{ Kinerja } \\
\hline & & $L$ & $\mathrm{P}$ & D-3 & S-1 & S-2 & Ringan & Sedang & Berat & Kurang & Cukup & Baik \\
\hline 1 & $\begin{array}{c}20 \text { tahun } \\
- \\
25 \text { tahun }\end{array}$ & 8 & 9 & 10 & 3 & 0 & 3 & 2 & 0 & 0 & 1 & 5 \\
\hline 2 & $\begin{array}{c}26 \text { tahun } \\
- \\
30 \text { tahun }\end{array}$ & 2 & 3 & 7 & 0 & 0 & 4 & 3 & 0 & 0 & 2 & 8 \\
\hline 3 & $\begin{array}{c}31 \text { tahun } \\
- \\
35 \text { tahun }\end{array}$ & 2 & 4 & 5 & 1 & 0 & 5 & 3 & 0 & 1 & 2 & 6 \\
\hline 4 & $\begin{array}{c}36 \text { tahun } \\
- \\
40 \text { tahun }\end{array}$ & 0 & 2 & 4 & 0 & 0 & 4 & 4 & 0 & 0 & 1 & 4 \\
\hline 5 & $\begin{array}{c}\text { di atas } \\
40 \text { tahun }\end{array}$ & 0 & 0 & 0 & 0 & 0 & 0 & 0 & 0 & 0 & 0 & \\
\hline & Total & 12 & 18 & 26 & 4 & 0 & 16 & 12 & 0 & 1 & 6 & 23 \\
\hline
\end{tabular}

Berdasarkan data pada Tabel 1 dapat diperoleh informasi bahwa jumlah responden sebagian besar adalah usia 20 tahun sampai dengan 25 tahun sebanyak 56,7 persen. Pada usia ini, seseorang masuk dalam rentang usia produktif, ketika seseorang masih mampu menghasilkan sesuatu.

Berdasarkan data tersebut, dapat diperoleh informasi bahwa jumlah responden sebagian besar berjenis kelamin perempuan sebanyak 60 persen. Perempuan dianggap sebagai pengurus utama yang mampu mengurus pasien dengan baik serta lebih banyak klien yang canggung atau malu jika dengan perawat laki-laki. Sisanya sebanyak 40 persen berjenis kelamin laki-laki dari 30 responden. Berdasarkan data tersebut dapat dilihat bahwa distribusi responden berdasarkan pendidikan sebagian besar berpendidikan D-3 sebanyak 26 orang atau 86,7 persen dari 30 responden. Pendidikan
D-3 merupakan syarat minimal untuk menjadi perawat di RS Wava Husada Kepanjen, Kabupaten Malang.

Berdasarkan data tersebut dapat dilihat bahwa distribusi responden berdasarkan tingkat stres sebagian besar mengalami stres ringan sebanyak 16 perawat atau 53,3 persen, mengalami stres sedang sebanyak 12 perawat atau 40 persen, dan mengalami stres berat sebanyak 2 perawat atau 6,7 persen. Kondisi ini menunjukkan perawat shift malam memiliki sebanyak 12 perawat atau 40 persen dan stres berat 2 perawat atau 6,7 persen. Kondisi ini menunjukkan bahwa dari 30 responden perawat shift malam, rata-rata mengalami stres kerja.

Berdasarkan data tersebut dapat dilihat bahwa distribusi responden sebagian besar memiliki kinerja baik, yaitu sebanyak 23 perawat atau 76,7 persen. Perawat dengan kinerja cukup sebanyak 6 perawat atau 20 
persen dari 30 responden.

Dilakukan uji statistik mengenai hubungan stres kerja shift malam dengan kinerja perawat pelaksana di ruang rawat inap RS Wava Husada Kepanjen, Kabupaten Malang. Hasil analisis statistik hubungan stres kerja dengan variabel kinerja perawat dapat terlihat pada Tabel 2 berikut ini.

Tabel 2. Tabulasi silang hubungan stres kerja shift malam dengan kinerja perawat pelaksana

\begin{tabular}{lccccccc}
\hline \multirow{2}{*}{ Stres Kerja } & \multicolumn{6}{c}{ Kinerja } & \multirow{2}{*}{ Total } \\
\cline { 2 - 6 } & \multicolumn{2}{c}{ Kurang } & \multicolumn{2}{c}{ Cukup } & \multicolumn{2}{c}{ Baik } & \\
\cline { 2 - 6 } & Jumlah & $\%$ & Jumlah & $\%$ & Jumlah & $\%$ & \\
\hline Ringan & 0 & 0 & 7 & 23,3 & 9 & 30 & 16 \\
Sedang & 0 & 0 & 0 & 0 & 12 & 40 & 12 \\
Berat & 1 & 3,3 & 0 & 0 & 1 & 3,3 & 2 \\
Total & 1 & 3,3 & 7 & 23,3 & 22 & 73,3 & 30 \\
\hline
\end{tabular}

Berdasarkan data pada Tabel 2 dapat dilihat bahwa perawat yang mengalami stres kerja ringan memiliki kinerja cukup sebanyak 7 perawat dan kinerja baik sebanyak 9 perawat. Perawat yang mengalami stres kerja sedang memiliki kinerja baik sebanyak 12 perawat. Perawat yang mengalami stres kerja berat memiliki kinerja kurang sebanyak 1 perawat. Tabel tabulasi silang menunjukkan terdapat nilai 0 atau di bawah angka 5 .
Nilai ekspektasi $<5$ tersebut menyebabkan uji spearman rank tidak dapat digunakan untuk menguji hipotesis penelitian. Untuk mengatasi kelemahan uji spearman rank tersebut digunakan Fisher probability exact test.

Hubungan stres kerja shift malam dengan kinerja perawat pelaksana di ruang rawat inap RS Wava Husada Kepanjen, Kabupaten Malang.

Tabel 3. Hasil analisis hubungan stres kerja shift malam dengan kinerja perawat pelaksana

Variabel

Stres kerja - kinerja
Fisher Probability Exact Test

Exact Sig
Berdasarkan data pada Tabel 3 DISKUSI didapatkan hasil value dari uji Fisher probability exact test sebanyak 8,465 dengan nilai exact significant 0,047 . (exact sig. $<5 \%)$. Hasil uji Fisher probability exact test menunjukkan terdapat hubungan antara stres kerja shift malam dan kinerja perawat pelaksana di ruang rawat inap RS Wava Husada Kepanjen, Kabupaten Malang.
8,465

\section{Stres Kerja Shift Malam}

Berdasarkan hasil penelitian didapatkan tingkatan stres kerja pada perawat shift malam yang terbagi menjadi tiga tingkatan stres, yaitu stres ringan, stres sedang, dan stres berat. Berdasarkan distribusi pada tingkatan stres kerja sebagian besar perawat shift malam pada klasifikasi stres ringan (16 perawat atau sebanyak 53,3 persen). 
Kebiasaan orang pada umumnya ialah tidur pada malam hari. Malam hari yang tenang memang secara alami diciptakan untuk istirahat. Perubahan pola istirahat ini tentunya memiliki dampak psikologis maupun fisik. Di samping itu, para perawat shift malam harus siap siaga menjaga dan melayani pasien dengan segala macam perilaku. Keadaan ini ditunjukkan dengan hasil penelitian bahwa sebagian besar perawat shift malam mengalami stres ringan.

Stres kerja merupakan kondisi ketegangan yang menciptakan adanya ketidakseimbangan fisik dan psikis, yang memengaruhi emosi, proses berpikir, dan kondisi seorang karyawan (Depkes RI, 2008). Stres merupakan kondisi ketegangan yang berpengaruh terhadap emosi, jalan pikiran, dan kondisi fisik seseorang (Sedamayanti, 2006). Ketegangan bisa disebabkan beban kerja dan rasa lelah dapat terjadi dan dirasakan oleh perawat shift malam. Beban tugas perawat shift malam memiliki beban lebih, yaitu harus mampu mengesampingkan rasa lelah dan mengantuk untuk memberikan layanan kepada pasien yang sewaktu-waktu membutuhkan layanannya (Megawaty, 2012).

Hasil penelitian ini memberikan gambaran bahwa perawat shift malam sebagian besar mengalami stres ringan, yaitu sebanyak 53,3 persen, sedangkan sebanyak 40 persen mengalami stres sedang dan 2 perawat mengalami stres berat. Hal ini mendukung teori bahwa pekerja shift malam akan mengalami rasa kantuk atau lelah karena kurang istirahat serta mengalami penurunan nafsu makan.

\section{Kinerja Perawat Shift Malam}

Berdasarkan hasil penelitian, didapati bahwa kinerja perawat shift malam sebagian besar pada kategori baik, yaitu 23 orang atau sebanyak 76,7 persen. Tugas perawat sebagai tenaga kesehatan ialah memberikan layanan kesehatan sesuai dengan asuhan keperawatan dengan sebaik-baiknya dengan mengesampingkan masalah pribadi, waktu, dan tempat. Di mana pun seorang perawat dibutuhkan untuk melayani pasien, ia harus selalu siap memberi layanan. Demikian juga perawat shift malam harus memiliki kesanggupan mempertahankan kinerjanya sebaik mungkin.

Dalam Undang-Undang (UU) Kesehatan No. 36 Tahun 2009 disebutkan bahwa kinerja keperawatan merupakan aktivitas yang diberikan kepada klien melalui pelaksanaan asuhan keperawatan untuk mencapai tujuan layanan kesehatan. Pembagian 3 shift ditujukan agar tidak terjadi penurunan produktivitas kerja pada perawat. Menurut Sarwono (2006), kinerja adalah hasil secara kualitas maupun kuantitas yang dicapai oleh seorang pegawai dalam melaksanakan tugasnya sesuai dengan tanggung jawab yang diberikan kepadanya.

Kinerja perawat pada shift malam tecermin pada hasil penelitian ini, yaitu sebagian besar perawat memiliki kinerja baik sebanyak 76,7 persen, perawat dengan kinerja cukup sebanyak 20 persen, serta perawat yang memiliki kinerja kurang sebanyak 3,3 persen. Banyak faktor yang memengaruhi kinerja perawat, antara lain tingkat keterampilan, hubungan antartenaga kerja, manajemen kinerja, kreativitas, tingkat penghasilan, lingkungan, sarana dan prasarana, sikap kerja seperti kesediaan untuk bekerja secara bergiliran (shift work) dan bekerja dalam suatu tim. Perawat bersedia bekerja secara bergiliran sesuai pembagian shift pekerjaan yang berat pada perawat shift malam, yakni harus selalu siap melayani pasien di saat jam istirahat. Selama perawat pada shift malam, tidak ada beban lain yang ditanggungnya, misalnya beban atau masalah keluarga, masalah ekonomi, atau masalah kehidupan lainnya, bekerja pada shift malam bukanlah suatu tugas yang 
berat. Hal ini terjadi karena perawat memang disiapkan untuk melakukan tugas dalam kondisi apa pun. Seorang perawat dididik untuk mengutamakan memberikan layanan kepada pasien.

\section{Hubungan antara Stres Kerja Shift Malam dan Kinerja Perawat Pelaksana di Ruang Rawat Inap RS Wava Husada Kepanjen, Kabupaten Malang.}

Hasil analisis hubungan antara stres kerja shift malam dan kinerja perawat pelaksana di ruang rawat inap RS Wava Husada Kepanjen Kabupaten Malang menunjukkan nilai signifikansi sebesar 0,000 . Hal ini menunjukkan bahwa terdapat hubungan antara stres kerja shift malam dan kinerja perawat pelaksana di ruang rawat inap RS Wava Husada Kepanjen Kabupaten Malang karena nilai signifikansi ( $p$ ) lebih kecil dari alfa $(\alpha)$.

Tekanan dalam bekerja merupakan hal yang banyak dialami pada sebagian pekerja malam. Hal ini disebabkan pola tidur yang tidak teratur. Di samping itu, perawat harus melayani pasien yang sewaktuwaktu membutuhkan tenaganya dengan kesiagaan yang penuh. Jika perawat shift malam dengan beban tugas yang berat ini mengalami tekanan atau stres, tentunya berdampak terhadap layanan yang diberikan atau menurunkan kualitas kerja.

Efek kerja shift malam ialah kualitas tidur pada siang hari tidak seefektif tidur malam, juga berisiko pada pencernaan, sistem saraf, jantung, dan pembuluh darah. Seseorang yang jarang tidur di malam hari mengalami penurunan nafsu makan sehingga berdampak pula terhadap gangguan pecernaan sehingga shift kerja malam juga dapat mengurangi kemampuan kerja, meningkatkan kesalahan dan kecelakaan, menghambat hubungan sosial dan keluarga dalam bermasyarakat (Wambrauw, 2006). Hasil penelitian menunjukkan hipotesis penelitian diterima yang artinya terdapat hubungan yang signifikan antara stres kerja shift malam dan kinerja perawat pelaksana di ruang rawat inap RS Wava Husada Kepanjen, Kabupaten Malang.

\section{SIMPULAN}

Streskerja shiftmalam dapatmenurunkan kinerja perawat pelaksana di ruang rawat inap RS Wava Husada Kepanjen, Kabupaten Malang. Institusi pelayanan kesehatan diharapkan mampu meningkatkan pelayanan kesehatan masyarakat yang seharusnya juga memperhatikan tenaga kesehatan, salah satunya perawat dengan memberikan motivasi, baik secara psikologis berupa penghargaan, insentif, maupun pelatihanpelatihan secara berkesinambungan sehingga dapat menekan terjadinya tekanan dalam menjalankan tugas serta dapat meningkatkan kinerja pelayanan kesehatan terhadap masyarakat.

\section{DAFTAR PUSTAKA}

Depkes RI. (2008). "Profil Kesehatan Indonesia 2008". http://www.depkes. go.id

Desak (2008). "Hubungan Stres dan Mekanisme Koping dengan Dukungan Sosial Keluarga dalam Merawat Pasien Gagal Ginjal Kronik di Unit Hemodialisa Rumah Sakit Pusat Angkatan Darat Gatot Subroto". Skripsi. Universitas Pembangunan Nasional Veteran, Jakarta.

Hasibuan, M.S.P. (2009). Manajemen Sumber Daya Manusia. Jakarta: PT Bumi Aksara.

Megawaty. (2012). Hubungan Efek Fisiologis Shift Malam dan Kinerja Perawat di Ruang Intensive Care Unit RSUD Kabupaten Malinau, Tesis, Fakultas Kesehatan Masyarakat. Universitas Sumatera Utara, Medan. 
Retyaningyas, D. (2005). "Hubungan Antara Stres Kerja dengan Produktivitas Kerja di Bagian Linting Rokok PT. Gentong Gotri Semarang". Semarang, Jurnal.

Sarwono, (2006). "Hubungan Masa Kerja dengan Stres Kerja pada Pustakawan Perpustakaan". Berkala IImu

Sedarmayanti. (2006). Sumber Daya Manusia dan Produktivitas Kerja. Bandung: Mandar Maju.

Stuart, G.W. (2007). Keperawatan Jiwa. Edisi 5. Jakarta: EGC.

Wambrauw, J. 2006. Analisis Faktor-Faktor Perpustakaan dan Informasi, Volume Yang Mempengaruhi Ketidakpatuhan Dokter Dalam Penulisan Resep Sesuai dengan Formularium Rumah Sakit Umum R.A. Kartini Jepara Tahun 2006, Tesis, Universitas Diponegoro, Semarang. 